\title{
Fertility of Privately Owned Plowland Used for Field Crop Production in Vojvodina, Serbia
}

\author{
Stanko Milić • Jovica Vasin • Jordana Ninkov• \\ Tijana Zeremski • Borislav Brunet • Petar Sekulić
}

received / primljeno: 10.01.2011. revised / prerađeno:14.03.2011. accepted / prihvaćeno: 27.04.2011.

(C) $2011 \mathrm{IFVC}$

\begin{abstract}
Summary: The paper presents the results of soil fertility analysis for different crop growing areas of Vojvodina, Serbia. The analysis was conducted on a total of 76,868 plowland samples, accounting for $87 \%$ of the total number of samples tested in a larger project. On average, the neutral soil reaction, which is the most favorable type of reaction for crop production, was found in one quarter of all samples in our study. The percentage of samples with such reaction ranged from 12.6\% (northern Bačka) to $46.5 \%$ (northern Srem). Looking at the free $\mathrm{CaCO}_{3}$ content by area, the highest mean value $(10.54 \%)$ and proportions of calcareous $(30.6 \%)$ and highly calcareous $(53.1 \%)$ samples were found in northern Bačka, while the lowest values of these parameters were recorded in northern Srem. When it comes to the soil humus content, all three areas of Srem were found to be mostly slightly humic, as according to our analysis they had between 72.1 and $83.3 \%$ of samples that were slightly humic and only a small proportion (16.2-27.3\%) of samples that are characterized as humic. Considering the readily available phosphorus content in Vojvodina as a whole, our analysis has shown that only one third of the soils in the province have an optimum supply of this element. What is of concern is that a considerable proportion of our samples were determined to be either very poor $(6.9 \%)$ or poor $(15.5 \%)$ in phosphorus, while about $7 \%$ had harmful or toxic levels of this macronutrient. In the case of the levels of readily available potassium, the largest number of the samples had either an optimum or high supply of the element. The sum of such samples ranged from 77.4 to $94.1 \%$ depending on the area.
\end{abstract}

Key words: basic chemical properties, crop growing areas, soil, soil fertility control

\section{Introduction}

The soil is one of the largest and most important natural resources for all of mankind. Excessive or careless use of soil will cause it to be come increasingly less productive and will eventually result in its destruction. The soil is a complex and dynamic system and its biological, chemical, and physical properties change under the influence of agricultural production. It has generally been accepted that intensive agricultural production degrades soil quality. Nevertheless, it is also true that adequate soil management and good agricultural practice (which involves regular checks of soil quality and adherence to the basic principles of fertilizer use and crop management)

S. Milić $(\bowtie) \cdot J$. Vasin • J. Ninkov • T. Zeremski • P. Sekulić Institute of Field and Vegetable Crops, Maksima Gorkog 30, 21000 Novi Sad, Serbia

Borislav Brunet

Provincial Secretariat for Agriculture, Water Management and Forestry, Bul. Mihajla Pupina 16, 21000 Novi Sad, Serbia can help maintain soil productivity with minimal impact on the environment. A good quality soil is characterized by high levels of available nutrients, good aeration, water infiltration, and retention, a stable structure, and high biological activity.

In protecting the soil from degradation of the greatest importance are making use of preventive measures, being able to identify potential risks, and finding the proper way to counter such threats. In this context, it is recommended that soil fertility and soil levels of hazardous and harmful substances are regularly controlled, i.e. that soil quality is monitored (Sekulić et al. 2005).

In scientific terms, the Soil Fertility and Fertilizer Use Control System (SFFUCS) was conceived at the Sixth Congress of the Yugoslav Soil Science Society (Congress Resolution, 1980). In 1985, the Assembly of the Autonomous Province of Vojvodina passed a law on the use of agricultural soils, by which the provisions of the SFFUCS were established among other things. The SFFUCS involves the control of all factors that determine soil fertility as well as the 
implementation of measures aimed at attaining high and stable crop production whilst adhering to the principles of economy and environmental friendliness.

In present times, when high-yielding, highquality cultivars and hybrids are commonly used, work on the issues of plant mineral nutrition needs to be intensified to an even greater degree. The reason for this lies in the fact that the variability of climatic factors and incomplete agronomic practices, which significantly affect nitrogen availability in the soil, often reduce the availability of nutrients to plants in conditions when not enough fertilizer is being used during crop growing (Bogdanović 2009).

According to the current Serbian Law on Agricultural Soils, Article 64, Paragraph 3 (Official Gazette of the Republic of Serbia , Issues No. 62/06, 65/08 and 41/09), in order to ensure the maintenance of chemical and biological properties of agricultural soils belonging to land quality classes I through $\mathrm{V}$ and the correct use of mineral and organic fertilizers and pesticides, the owner or user of a tract of arable agricultural land is obligated to control soil fertility on such land and to keep records of the amount of mineral fertilizer and pesticide incorporated into said soil. These checks are to be performed as needed, but not less frequently than every five years.

The advancement of agricultural production on privately-owned tracts of land (for instance, by striving towards a more sensible use of fertilizer through the use of the SFFUCS) has a lot of potential to greatly contribute to the development of Serbian agriculture in general, since around $70 \%$ of plowland and garden land in Vojvodina are privately owned (Statistical Office of the Republic of Serbia 2010) In the case of field crops, the lower limit of the optimum supply of phosphorus and potassium in a soil has been found to be $15 \mathrm{mg} / 100 \mathrm{~g}$ soil (Manojlović 1986). This value is also the threshold below which the absence of fertilizer application should have no negative influence on yield.

The objective of this paper was to underscore the importance of the SFFUCS as well as to assess the soil fertility status in different cropgrowing regions of Vojvodina with respect to the major biogenic elements.

\section{Materials and Methods}

Since 2002, the Secretariat for Agriculture, Water Management, and Forestry of the Province of Vojvodina and the Institute of Field and Vegetable Crops in Novi Sad along with a network of regional expert agricultural services have been running a program in which they analyze soil from privately-owned plots in Vojvodina and then provide adequate fertilization recommendations, with both services being provided free of charge. The idea behind the program is for soil analysis, which is a major component of the SFFUCS, to

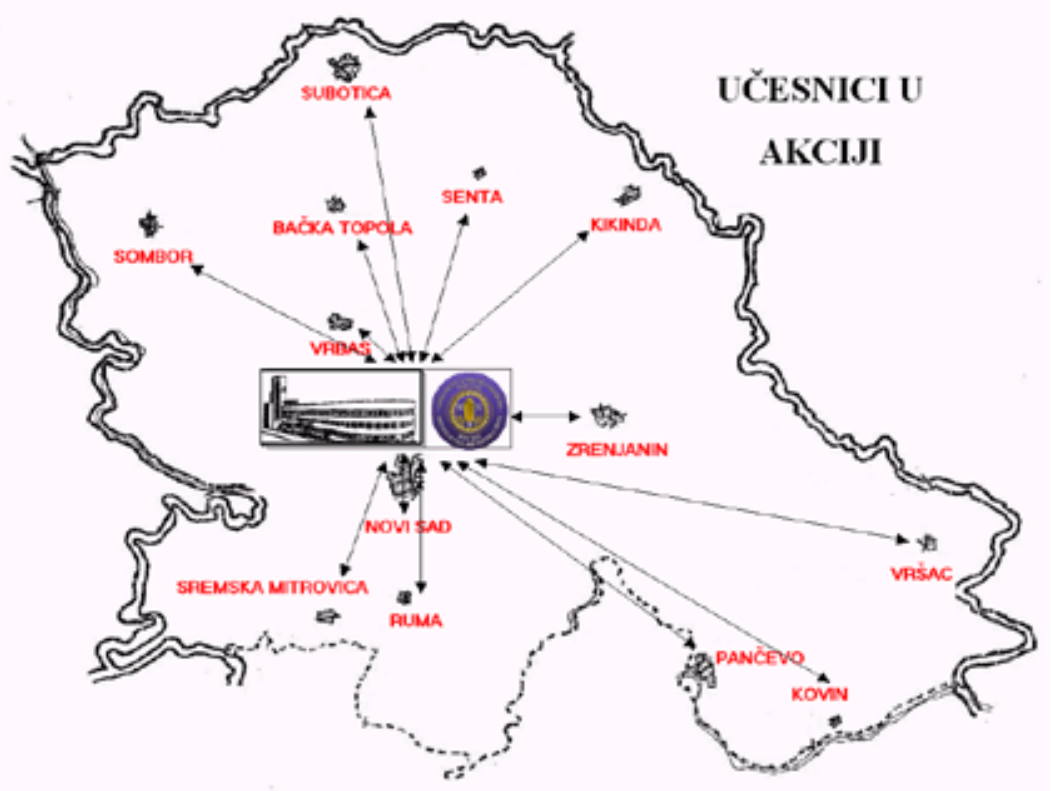

Figure 1. Participants in the SFFUCS program

Slika 1. Učesnici u sistemu kontrole plodnosti zemljišta Vojvodine 
become more popular among crop growers until it becomes a widely used practice again.

The samples were analyzed at the Institute of Field and Vegetable Crops in Novi Sad and by the regional expert agricultural services (Fig. 2). A total of over 88,350 samples have been tested so far, and out of these $76,868(87 \%)$ are samples of plowland soil.

The methods used in the analyses are those recommended by the Yugoslav Soil Science Society (YSSS 1966).

The following parameters of soil fertility have been analyzed in laboratory conditions during the program:

- $\mathrm{pH}$ value in a soil suspension using potassium chloride

- $\mathrm{CaCO}_{3}$ content - on a calcimeter according to Scheibler

- humus content - by Tiurin's method

- readily available phosphorus - by the AL method

- readily available potassium - by the $\mathrm{AL}$ method

In the present paper, we discuss mean, minimum, and maximum values of the main soil fertility parameters and the percentage proportion of samples within a particular value range for each individual parameter.

\section{Results and Discussion}

The province of Vojvodina has a high potential for intensive agricultural production thanks to its richness in good quality soil, mild climate, abundance of water, and long tradition of crop growing. With its $1,612,000$ ha of arable land
(Stat. Yearbook 2010), Vojvodina is an agricultural region of outstanding importance.

Of the province's total area of 2,150,600 ha, as much as $81.26 \%(1,747,000 \mathrm{ha})$ is agricultural land, with $74.6 \%$ of the total area being arable. Land in Vojvodina is predominantly used for the production of field and vegetable crops, as plowland and garden land account for as much as $90 \%$ of total arable land (Fig. 2).

\section{Crop growing areas of Vojvodina}

Vojvodina as a whole can be considered a single, unified agroecological region, especially when it comes to the growing of field and vegetable crops. Nevertheless, there are certain differences that exist among different areas of Vojvodina with respect to climate and soil, to some extent. The differences among the different areas are more pronounced in the case of climate than in that of soil, because the dominant types of soil in Vojvodina, chernozem and hydromorphic black soil, cover more than $75 \%$ of the total area of the province.

According to Živković et al. (1972), the two predominant soil types, chernozem and hydromorphic black soil, are not distributed uniformly throughout the province, i.e. its different areas differ in this respect among themselves. In this connection, the three main geographic regions in Vojvodina - Bačka, Banat and Srem - can be also viewed as three distinct climatic regions: the western, eastern, and southern. The aforementioned differences in the distribution of individual soil types by region also make it possible to view the three main regions of the province as somewhat distinct in this

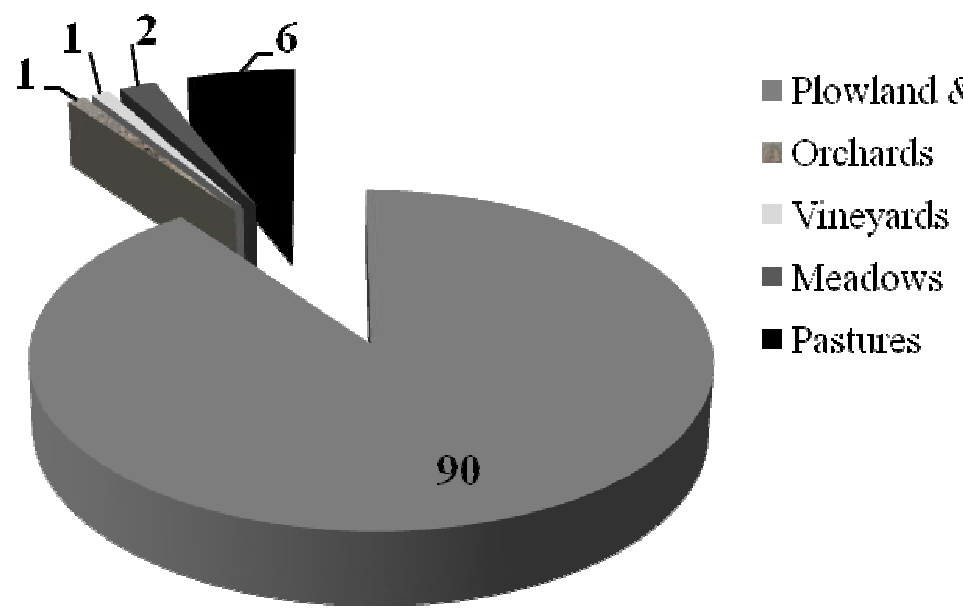

Figure 2. Percentage contribution of different types of land use in Vojvodina (\%), source Statistical Office of the Republic of Serbia, 2010

Slika 2. Zastupljenost pojedinih načina korišćenja zemljišta u Vojvodini (\%) (RZS, 2010) 


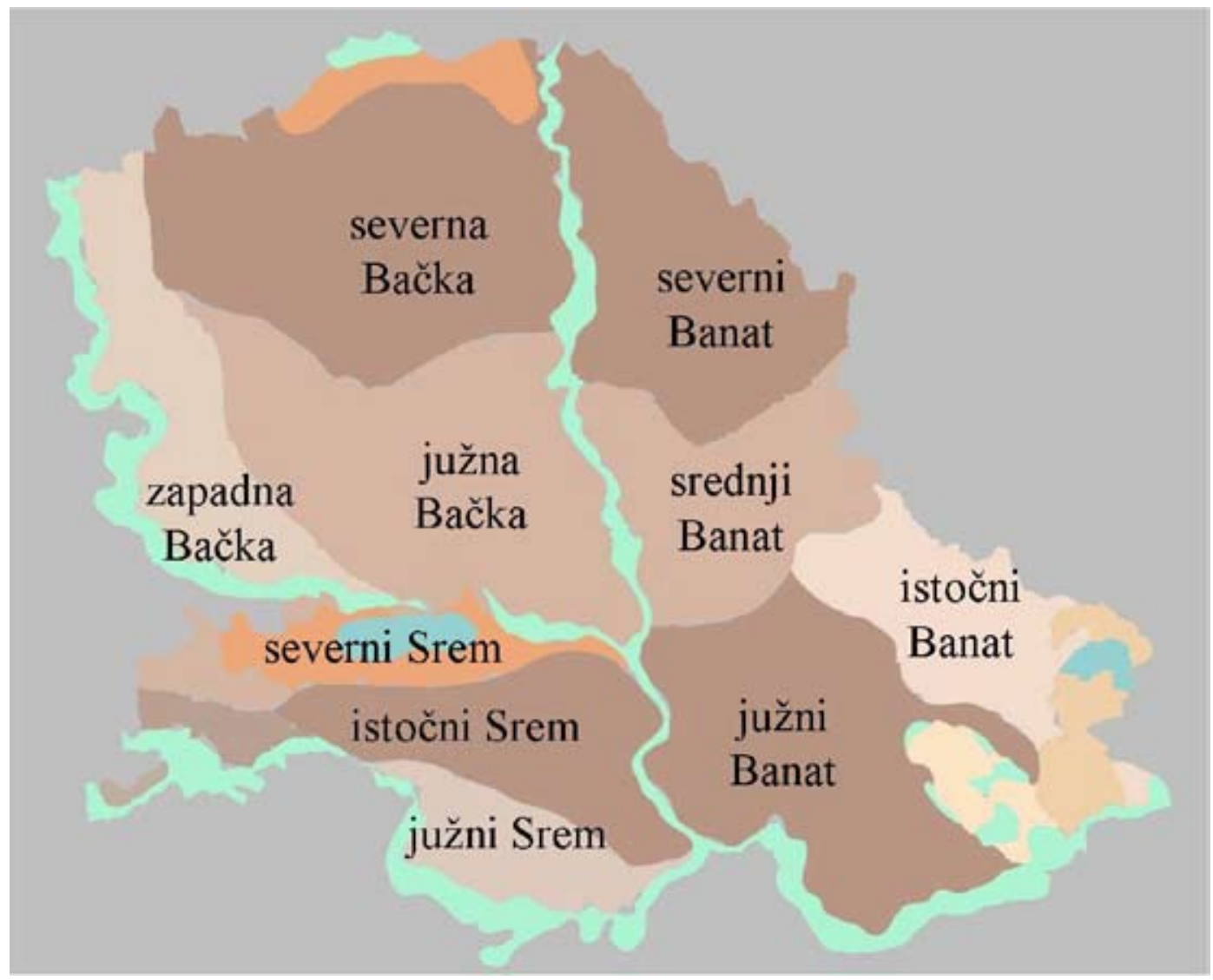

Figure 3. Crop production areas of Vojvodina Slika 3. Skica proizvodnih rejona u Vojvodini regard as well. Within the three regions, there are 10 distinct areas of field crops production alongside some areas in which fruit and vine growing predominate and some dedicated to special types of crop production (Fig. 3). The main differences among these areas primarily have to do with climatic conditions, although differences among adjacent areas are often not completely differentiated. These differences make it necessary to apply certain agronomic practices in order to make better use of climatic conditions at hand or to mitigate the effects of climatic extremes. The most important among such practices are the choice of crop species or cultivar to be grown in a given area, the crop growing technology which is to be used (most notably tillage and fertilizer application), and plant density in the case of some crops to an extent. Soil conditions (the positive and negative sides of the soil) will also dictate that certain agricultural practices be applied in order to create optimal production conditions for a given crop.
2. Soil fertility in different crop growing areas of Vojvodina

\subsection{Soil reaction}

The average results of our analysis of the soils of Vojvodina show that acidic soils are very uncommon in the province, as the three variations of such soil (highly acidic, acidic, and slightly acidic) combined accounted for only $14.2 \%$ of all the samples in our study. Most of the samples analyzed (61.1\%) were found to be slightly alkaline, as they fell within the $\mathrm{pH}$ 7.218.20 range, and the average soil reaction value in the samples as a whole was 6.98 (Tab. 1). However, on an area-to-area basis, there is a lot of variation in the distribution of slightly alkaline soils in Vojvodina. The lowest percentage of such soils is found in southern Srem (31.2\%) and the highest in northern Bačka (85.5\%). These results are in agreement with the findings of a study by Vasin et al. (2006), in which nearly half the soil samples analyzed proved to be slightly alkaline. According to the authors of that study, such high percentage 
of soils of said type is unfavorable, because it limits the uptake of most plant nutrients as well as the application of certain types of mineral fertilizer.

On average, the neutral soil reaction, which is the most favorable type of reaction for crop production, was found in one quarter of all samples in the present study. The percentage of samples with such reaction ranged from 12.6\% (northern Bačka) to $46.5 \%$ (northern Srem). In most of the crop growing areas studied, the average values of exchangeable acidity $(\mathrm{pH}$ in $\mathrm{KCl}$ ) were within the range found in neutral soils. The only exceptions to this were southern and northern Bačka and eastern Banat (Tab. 2).

\section{2. $\mathrm{CaCO}_{3}$ content}

The $\mathrm{CaCO}_{3}$ content of the samples we analyzed ranged between 0 and $63.1 \%$, averaging $5.8 \%$ (Tab. 1). The largest proportions of the samples were found to be calcareous $\left(26.7 \%\right.$, a $\mathrm{CaCO}_{3}$ content of 5 to $10 \%$ ) and highly calcareous $\left(26.4 \%\right.$, a $\mathrm{CaCO}_{3}$ content of over $\left.10 \%\right)$, which is in agreement with the results reported by Nešić et al. (2008). Looking at the free $\mathrm{CaCO}_{3}$ content by area, it can be observed that this content is correlated with soil reaction (Tab. 2). Thus, the highest mean value (10.54\%) and proportions of calcareous $(30.6 \%)$ and highly calcareous $(53.1 \%)$ samples were found in northern Bačka, while the lowest values of these parameters were recorded in northern and southern Srem.

Northern and southern Srem, western Bačka, and eastern and northern Banat are characterized by low levels of free $\mathrm{CaCO}_{3}$. In our study, each of these areas had more than $40 \%$ of soil samples with less than $2 \%$ of free $\mathrm{CaCO}_{3}$. Low soil levels of $\mathrm{CaCO}_{3}$ are important primarily because of the reduced positive effects of $\mathrm{Ca}$ ions on soil structure (Vasin et al. 2004). High percentages of soil samples with an extremely high $\mathrm{CaCO}_{3}$ content were found in northern Bačka (53.1\%), southern Bačka (30.3\%), central Banat (23.7\%), and southern Banat $(22.3 \%)$. Because of such high $\mathrm{CaCO}_{3}$ levels, the risks of potential damage due to the immobilization of uptake of certain micronutrients by plants are quite pronounced in these areas. Additionally, the most common byproduct of high $\mathrm{CaCO}_{3}$ levels on these soils is soil alkalinity. Differences such as these among the different crop growing areas of Vojvodina can be attributed to differences in pedogenesis. It is of utmost importance that good agricultural practice be implemented on these soils, most notably that acidic mineral and organic fertilizers be incorporated into the active rhizosphere zone. In accordance with this, when using specific nitrogen fertilizers, preference should be given to acidic fertilizers (urea, $\mathrm{AN}$, ammonium sulfate).

\subsection{Humus}

The areas of Vojvodina from which the samples for our study were collected predominantly belong in the class of humic soils (59.1\%), with an average humus content of $3.01 \%$ (Tab. 1 and 2). However, looking at how the different humus levels are distributed among the different crop growing areas of the province, it can be observed that all three areas of Srem are for the most part slightly humic, as in our study they had between $72.1 \%$ and $83.3 \%$ of samples that were slightly humic and only a small proportion (16.2-27.3\%) of samples that are characterized as humic. A similar situation exists in the area of western Bačka, in which $68 \%$ of the samples were slightly humic and $29.7 \%$ humic. In the other areas, the situation with respect to the distribution of humus levels is very similar. The largest proportions of the samples from these areas were found to be humic (52-71.1\%) or slightly humic (21.6-45.2\%). The proportions of highly humic soil samples across the areas studied were very low and none exceeded 1.6\% except for the area of eastern Banat, where there were $2.8 \%$ of such samples. The soils of Vojvodina were initially very rich in organic matter. At the start of the previous decade, however, it was observed that there was a trend towards a decrease in soil humus levels in the province when compared to previous studies (Bogdanović et al. 1993), and this negative trend has been continuing ever since. A reduction in the humus content most often occurs when no organic fertilizer is incorporated into the soil during crop growing and crop residues are burned in the fields after the harvest (Sekulić et al. 2010), which results in a reduced capacity for humus mineralization and hence in the release of mineral nutrients.

\subsection{Readily available phosphorus content}

Our analysis indicates that the readily available $\mathrm{P}$ content in Vojvodina ranges between 0.1 and $621.4 \mathrm{mg} / 100 \mathrm{~g}$ soil, averaging $23.77 \mathrm{mg} / 100 \mathrm{~g}$ soil (Tab. 1). This would seem to suggest that on average the soils of Vojvodina are well supplied with the element. In the present study, however, only one third of the soil samples were found to have an optimum supply of $\mathrm{P}$. What is of concern is that a considerable proportion of our samples 
were determined to be either very poor $(6.9 \%)$ or poor $(15.5 \%)$ in phosphorus, while about $7 \%$ had harmful or toxic levels of this macronutrient.

Our study's findings indicate that readily available $\mathrm{P}$ is fairly evenly distributed across the different crop growing areas of Vojvodina, with the values for each specific area being more or less similar to the average values for the province as a whole.

The levels of readily available $\mathrm{P}$ in the soils of Vojvodina also reflect the mistakes crop growers have made in the past with respect to fertilizer application. The sum of soils that are poor or very poor in $\mathrm{P}$ ranges from $13.7 \%$ to $29.6 \%$ depending on the area of the province. The areas with the largest number of such samples were southern Srem (29.6\%), western Bačka (28.9\%), northern Banat (28.5\%), and eastern Banat $(23 \%)$. When it comes to the sum of soils with very high to harmful and toxic levels of $\mathrm{P}$, the values we recorded ranged from $4.1 \%$ to $13.2 \%$. The highest values were found in samples from western Bačka, northern Srem, eastern Banat, and southern Bačka.

The largest percentage of samples with an optimal supply of readily available $\mathrm{P}$ was found in the areas of northern Bačka (37.2\%), central Banat (37.1), southern Banat (36.8\%), southern Bačka (32.8\%), and eastern Srem (31.3\%). Soils with a high supply of this element were the most common in southern Bačka (21.1\%), northern Bačka (20.5\%), northern Srem (19.0\%), and eastern and central Banat (18.3\% and 18.5\%, respectively). Northern Bačka, central Banat, and southern Bačka are areas in which it would be possible to make reductions in the amounts of phosphorus fertilizers used, because soils with an optimal or high supply of the element are predominant in them. Harmful or toxic levels of readily available $\mathrm{P}$ are most commonly found on plots on which intensive vegetable production takes place. The extremely high values of readily available $\mathrm{P}$ that are found in some such cases are due to the relative smallness of the areas being used for crop growing as well as to the high profitability of the production, but they may also be a product of incompetence on the part of the crop grower. In the present study, the maximum values of $P$ ranged from 253.0 to $621.4 \mathrm{mg} / 100 \mathrm{~g}$ depending on the area.

Some crop species have high requirements for mineral substances and are thus subjected to intensive fertilization on a regular basis. However, in a desire to maximize yields and through a lack of competence, fertilizers are often introduced into the soil in excessive amounts, which results in an imbalance in plant nutrition, causes a variety of changes in the biological balance of the agroecosystem, and ultimately affects yield quality (Wu et al. 1998, Kraus et al. 2000).

\subsection{Readily available potassium content}

The largest proportion of the samples from our study $(42.6 \%)$ had readily available potassium levels ranging between 25 and 50 $\mathrm{mg} / 100 \mathrm{~g}$, indicating a high soil supply of this element. A high proportion of the samples (42.3\%) were optimally supplied with $K$ as well $(15-25 \mathrm{mg} / 100 \mathrm{~g})$. Such levels of $\mathrm{K}$ in the soils of Vojvodina can be attributed to pedogenetic characteristics (K-rich parent materials that underlie the soils of the province) as well as to inadequate fertilizer application on the part of crop growers (Tab. 2).

The highest average values of readily available $\mathrm{P}$ in the soil were recorded in the region of Banat - $42.1 \mathrm{mg} / 100 \mathrm{~g}$ soil in northern Banat and 38.7 $\mathrm{mg} / 100 \mathrm{~g}$ soil in central Banat. These values are considerably above the provincial average of $29.4 \mathrm{mg} / 100 \mathrm{~g}$. The averages for the regions of Srem and Banat were somewhat lower than the provincial average.

The proportion of samples with a very low $\mathrm{Al}$ $\mathrm{K}_{2} \mathrm{O}$ content $(0-5 \mathrm{mg} / 100 \mathrm{~g})$ was negligible and did not exceed $0.1 \%$ in any of the crop growing areas in our study. The percentage of soils that are poor in $\mathrm{Al} \mathrm{K}_{2} \mathrm{O}(5-10 \mathrm{mg} / 100 \mathrm{~g})$ was the largest in western Bačka (3.8\%), southern Banat (1.7\%) northern Bačka, and northern Srem (1.2\%). In the rest of the areas, the percentage of such soils was below $1 \%$. Most of the samples in all the areas analyzed had either an optimum or high supply of readily available potassium. The sum of such samples ranged from $77.4 \%$ to $94.1 \%$ depending on the area. This indicates that there is a great potential for reducing fertilization with this nutrient on most privately owned tracts of plowland in the province. The highest percentages of soils with an optimum or high $\mathrm{K}$ supply were recorded in southern Srem (94.1\%), eastern Srem (93.2\%), and southern Bačka (89.0\%).

In the case of samples with very high to harmful or toxic levels of readily available potassium, the largest sums of these two types of soil were found in the region of Banat (northern Banat - 21.2\%; central Banat - 14.9\%; eastern Banat $9.2 \%)$. 
Table 1. Minimum, maximum, and mean values of major chemical properties of soils from different crop growing areas of Vojvodina

Tabela 1. Minimalne, maksimalne i prosečne vrednosti osnovnih hemijskih svojstava zemljišta u različitim proizvodnim rejonima Vojvodine

\begin{tabular}{|c|c|c|c|c|c|c|}
\hline \multirow[t]{2}{*}{ Area } & \multirow{2}{*}{$\begin{array}{c}\text { Parameter } \\
\text { Min. }\end{array}$} & \multirow{2}{*}{$\begin{array}{c}\mathrm{pH} \mathrm{KCl} \\
3.0\end{array}$} & \multirow{2}{*}{$\frac{\mathrm{CaCO}_{3}(\%)}{0.0}$} & \multirow{2}{*}{$\begin{array}{c}\text { Humus }(\%) \\
0.17\end{array}$} & (mg/100g soil) & $\begin{array}{l}\mathrm{Al} \mathrm{K}_{2} \mathrm{O} \\
\text { soil) }\end{array}$ \\
\hline & & & & & 0.1 & 2.6 \\
\hline \multirow[t]{3}{*}{ Southern Srem } & Max. & 8.95 & 33.71 & 11.45 & 253 & 384 \\
\hline & Mean & 6.69 & 3.83 & 2.64 & 20.03 & 26.25 \\
\hline & Min. & 4.19 & 0.00 & 0.02 & 0.1 & 5.0 \\
\hline \multirow[t]{3}{*}{ Northern Srem } & Max. & 8.19 & 36.29 & 7.2 & 286.5 & 316.4 \\
\hline & Mean & 6.96 & 5.50 & 2.3 & 24.00 & 24.42 \\
\hline & Min. & 3.4 & 0.0 & 0.08 & 0.2 & 3.1 \\
\hline \multirow[t]{3}{*}{ Eastern Srem } & Max. & 8,59 & 40.43 & 11.41 & 270.5 & 320.13 \\
\hline & Mean & 7.23 & 5.93 & 2.61 & 22.82 & 25.91 \\
\hline & Min. & 3.53 & 0.0 & 0.01 & 0.1 & 2.0 \\
\hline \multirow[t]{3}{*}{ Southern Bačka } & Max. & 8.47 & 50.63 & 11.6 & 400.0 & 262.9 \\
\hline & Mean & 7.22 & 6.96 & 3.25 & 27.0 & 29.02 \\
\hline & Min. & 3.37 & 0.00 & 0.09 & 0.10 & 4.0 \\
\hline \multirow[t]{3}{*}{ Northern Bačka } & Max. & 8.44 & 85 & 11.45 & 440 & 384 \\
\hline & Mean & 7.45 & 10.54 & 3.49 & 24.80 & 25.81 \\
\hline & Min. & 3.53 & 0.0 & 0.02 & 0.1 & 3.5 \\
\hline \multirow[t]{3}{*}{ Western Bačka } & Max. & 8.26 & 44.28 & 12.44 & 600 & 417.9 \\
\hline & Mean & 7.06 & 5.72 & 2.67 & 29.166 & 25.63 \\
\hline & Min. & 3.5 & 0.00 & 0.01 & 0.4 & 3.95 \\
\hline \multirow[t]{3}{*}{ Southern Banat } & Max. & 8.4 & 56.71 & 9.78 & 378 & 240 \\
\hline & Mean & 7.12 & 6.10 & 3.12 & 20.33 & 27.04 \\
\hline & Min. & 3.31 & 0.00 & 0.01 & 0.1 & 5.03 \\
\hline \multirow[t]{3}{*}{ Central Banat } & Max. & 8.27 & 63.1 & 11.65 & 621.4 & 331.2 \\
\hline & Mean & 6.98 & 5.47 & 3.38 & 27.34 & 38.69 \\
\hline & Min. & 3.44 & 0.00 & 0.13 & 0.10 & 5.0 \\
\hline \multirow[t]{3}{*}{ Northern Banat } & Max. & 8.07 & 42.2 & 11.7 & 621.4 & 377.6 \\
\hline & Mean & 6.90 & 3.99 & 3.45 & 23.81 & 42.1 \\
\hline & Min. & 3.31 & 0.00 & 0.39 & 0.10 & 5.03 \\
\hline \multirow[t]{3}{*}{ Eastern Banat } & Max. & 8.9 & 37.32 & 11.53 & 389 & 331.2 \\
\hline & Mean & 6.47 & 3.89 & 3.12 & 26.62 & 30.09 \\
\hline & Min. & 3.0 & 0.0 & 0.01 & 0.1 & 1.2 \\
\hline \multirow[t]{2}{*}{ Vojvodina Average } & Max. & 8.90 & 63.1 & 12.44 & 621.4 & 417.95 \\
\hline & Mean & 6.98 & 5.80 & 3.01 & 23.77 & 29.04 \\
\hline
\end{tabular}


Table 2. Percentage contribution of samples within a particular value range of different fertility parameters

Tabela 2. Procentualna zastupljenost uzoraka zemljišta po klasama obezbeđenosti za posmatrane parametre plodnosti u različitim proizvodnim rejonima Vojvodine

\begin{tabular}{|c|c|c|c|c|c|c|c|c|c|c|c|c|}
\hline & \multirow{3}{*}{ Value range } & \multicolumn{11}{|c|}{ Crop growing area ( $\%$ of samples) } \\
\hline & & \multicolumn{3}{|c|}{ SREM } & \multicolumn{3}{|c|}{ BAČKA } & \multicolumn{4}{|c|}{ BANAT } & \multirow{2}{*}{$\begin{array}{l}\text { Vojv. } \\
\text { Mean }\end{array}$} \\
\hline & & $\mathrm{N}$ & $\mathrm{E}$ & $\mathrm{S}$ & $\mathrm{N}$ & W & S & $\mathrm{E}$ & $\mathrm{C}$ & $\mathrm{N}$ & $\mathrm{S}$ & \\
\hline \multirow{5}{*}{ 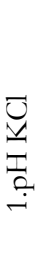 } & 1. Highly acidic $<4.50$ & 0.7 & 0.1 & 1.2 & 0.2 & 1.4 & 0.0 & 2.0 & 0.2 & 0.3 & 0.2 & 0.6 \\
\hline & 2. Acidic 4.51-5.50 & 3.5 & 1.0 & 12.3 & 0.4 & 4.9 & 1.3 & 10.7 & 3.4 & 6.2 & 1.7 & 4.4 \\
\hline & 3. Slightly acidic $5.51-6.50$ & 15.0 & 6.2 & 21.5 & 1.2 & 10.1 & 5.6 & 13.0 & 9.0 & 16.4 & 7.5 & 9.2 \\
\hline & 4. Neutral 6.51-7.20 & 46.5 & 30.1 & 33.7 & 12.6 & 34.0 & 23.0 & 27.4 & 25.1 & 31.1 & 22.3 & 24.6 \\
\hline & 5. Slightly alkaline $7.21-8.20$ & 34.3 & 62.4 & 31.2 & 85.5 & 49.6 & 70.1 & 46.9 & 62.3 & 46.0 & 68.3 & 61.1 \\
\hline \multirow{6}{*}{ 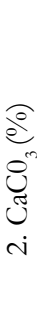 } & 6. Alkaline $>8.21$ & 0.0 & 0.2 & 0.1 & 0.1 & 0.0 & 0.0 & 0.0 & 0.0 & 0.0 & 0.0 & 0.0 \\
\hline & 1. Limeless 0.00 & 7.9 & 1.7 & 11.5 & 1.1 & 4.5 & 4.3 & 6.10 & 4.6 & 7.0 & 4.4 & 4.9 \\
\hline & 2. Slightly calcareous $0.01-2.00$ & 34.2 & 19.2 & 39.6 & 5.7 & 35.5 & 19.3 & 35.8 & 20.6 & 38.0 & 19.3 & 24.1 \\
\hline & 3. Medium calcareous $2.01-5.00$ & 25.2 & 22.0 & 20.7 & 9.5 & 17.7 & 18.7 & 19.5 & 17.0 & 18.7 & 24.2 & 17.9 \\
\hline & 4. Calcareous 5.01-10.00 & 21.2 & 34.4 & 19.3 & 30.6 & 19.4 & 27.4 & 24.2 & 34.2 & 23.6 & 29.8 & 26.7 \\
\hline & 5. Highly calcareous $>10.01$ & 11.5 & 22.7 & 8.9 & 53.1 & 22.9 & 30.3 & 14.4 & 23.7 & 12.7 & 22.3 & 26.4 \\
\hline \multirow{5}{*}{ 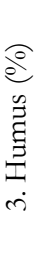 } & 1. Very slightly humic $0.00-1.00$ & 2.4 & 0.2 & 0.1 & 0.6 & 1.5 & 0.8 & 0.0 & 0.1 & 0.2 & 0.1 & 0.5 \\
\hline & 2. Slightly humic $1.01-3.00$ & 74.0 & 72.1 & 83.3 & 21.6 & 68.0 & 25.2 & 45.2 & 21.3 & 30.7 & 36.4 & 39.1 \\
\hline & 3. Humic 3.01-5.00 & 22.9 & 27.3 & 16.2 & 76.4 & 29.7 & 72.9 & 52.0 & 77.1 & 67.5 & 62.8 & 59.1 \\
\hline & 4. Highly humic 5.01-10.00 & 0.7 & 0.4 & 0.4 & 1.3 & 0.7 & 1.1 & 2.8 & 1.4 & 1.6 & 0.7 & 1.2 \\
\hline & 5. Very highly humic $>10.01$ & 0.0 & 0.0 & 0.0 & 0.1 & 0.1 & 0.0 & 0.0 & 0.0 & 0.0 & 0.0 & 0.0 \\
\hline \multirow{4}{*}{ 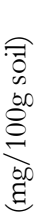 } & 1. Very poor $0.00-5.00$ & 7.5 & 4.71 & 7.9 & 2.8 & 10.6 & 5.4 & 8.6 & 6.2 & 10.0 & 4.1 & 6.9 \\
\hline & 2. Poor $5.01-10.00$ & 15.9 & 15.6 & 21.7 & 10.9 & 18.3 & 12.8 & 14.4 & 12.2 & 18.5 & 15.2 & 15.5 \\
\hline & 3. Medium 10.01-15.00 & 21.8 & 26.02 & 26.2 & 22.0 & 18.6 & 19.15 & 19.2 & 19.9 & 20.3 & 23.0 & 21.4 \\
\hline & 4. Optimal 15.01-25.00 & 25.6 & 31.3 & 23.5 & 37.2 & 21.6 & 32.81 & 29.6 & 37.1 & 27.5 & 36.8 & 31.1 \\
\hline \multirow{3}{*}{$\begin{array}{l}0^{n} \\
a^{N} \\
z \\
\dot{+}\end{array}$} & 5. High 25.01-50.00 & 19.0 & 15.0 & 13.2 & 20.5 & 17.7 & 21.1 & 18.3 & 18.5 & 17.1 & 16.9 & 17.7 \\
\hline & $\begin{array}{l}\text { 6. Very high to harmful } \\
50.01-100.00\end{array}$ & 6.8 & 5.1 & 5.3 & 5.3 & 7.1 & 5.9 & 6.08 & 3.7 & 4.6 & 2.8 & 5.0 \\
\hline & 7. Toxic $>100.01$ & 3.4 & 2.2 & 2.2 & 1.3 & 6.1 & 2.9 & 3.74 & 2.5 & 2.0 & 1.3 & 2.4 \\
\hline \multirow{7}{*}{ 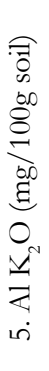 } & 1. Very poor $0.00-5.00$ & 0.1 & 0.0 & 0.0 & 0.0 & 0.1 & 0.1 & 0.0 & 0.0 & 0.0 & 0.0 & 0.1 \\
\hline & 2.Poor 5.01-10.00 & 1.2 & 0.2 & 0.1 & 1.3 & 3.8 & 1.0 & 0.4 & 0.1 & 0.2 & 1.7 & 1.3 \\
\hline & 3. Medium 10.01-15.00 & 5.7 & 3.5 & 2.8 & 8.7 & 14.7 & 3.8 & 7.0 & 1.0 & 1.0 & 9.0 & 6.6 \\
\hline & 4. Optimal 15.01-25.00 & 46.2 & 54.8 & 54.8 & 53.9 & 48.0 & 43.7 & 34.4 & 19.7 & 12.7 & 47.5 & 42.3 \\
\hline & 5. High 25.01-50.00 & 42.4 & 38.4 & 39.3 & 32.6 & 29.4 & 45.3 & 48.9 & 64.3 & 64.7 & 37.3 & 42.6 \\
\hline & $\begin{array}{l}\text { 6. Very high to harmful } \\
50.01-100.00\end{array}$ & 4.3 & 2.9 & 2.8 & 3.3 & 3.6 & 5.6 & 8.4 & 14.0 & 20.0 & 4.1 & 6.7 \\
\hline & 7. Toxic $>100.01$ & 0.1 & 0.2 & 0.2 & 0.2 & 0.4 & 0.5 & 0.8 & 0.9 & 1.2 & 0.3 & 0.5 \\
\hline
\end{tabular}




\section{Conclusions}

The neutral soil reaction (the most favorable type of soil reaction in crop production terms) was found in one quarter of all the samples on average, ranging from 12.6\% (northern Bačka) to $46.5 \%$ (northern Srem). In most of the areas studied, the average values of exchangeable acidity $(\mathrm{pH}$ in $\mathrm{KCl}$ ) were within the neutral range, with the only exceptions being southern and northern Bačka and eastern Banat.

Highly calcareous soils are the most common in the regions of Bačka and Banat (northern Bačka - 53.1\%, southern Bačka - 30.3\%, central Banat - 23.7\%, and southern Banat - 22.3\%). In these areas, there is considerable potential danger from the immobilization of certain micronutrients. It is highly important that good agricultural practice be implemented on these soils, most notably that physiologically acidic mineral and organic fertilizers be incorporated into the active rhizosphere zone (when using specific nitrogen fertilizers, preference should be given to acidic fertilizers, such as urea, $\mathrm{AN}$, and ammonium sulfate).

The three areas in the region of Srem are mostly slightly humic, as they were found to have between $72.1 \%$ and $83.3 \%$ of samples that were slightly humic and only a small proportion (16.2-27.3\%) of samples that are characterized as humic. A similar situation exists in the area of western Bačka, in which $68 \%$ of the samples were slightly humic and $29.7 \%$ humic. In the other areas, the situation with respect to the distribution of humus levels is very similar, with the highest proportions of the samples being humic (52$71.1 \%$ ) or slightly humic (21.6-45.2\%).

The levels of readily available $\mathrm{P}$ in the soils of Vojvodina reflect the mistakes crop growers have made over the previous period when it comes to fertilizer application. The sum of soils that are poor or very poor in $\mathrm{P}$ ranges from $13.7 \%$ to $29.6 \%$ depending on the area of the province. Northern Bačka, central Banat, and southern Bačka are areas in which it would be possible to make reductions in the amounts of phosphorus fertilizers used, because soils with an optimal or high supply of the element are predominant in them.

Most of the samples in all the areas we analyzed had either an optimum or high supply of readily available potassium, with the sum of such samples ranging between $77.4 \%$ and $94.1 \%$ depending on the area. This suggests that there is a great potential for reducing fertilization with this nutrient element on most privately owned tracts of plowland in the province.

\section{References}

Jugoslovensko društvo za proučavanje zemljišta (1980): Rezolucija VI Kongresa Jugoslovenskog društva za proučavanje zemljišta, Publikacija VI Kongres Jugoslovenskog društva za proučavanje zemljišta, Novi Sad, 26-27

Bogdanović D, Ubavić M, Dozet D (1993): Hemijska svojstva i obezbeđenost zemljišta Vojvodine neophodnim makroelementima. U: R Kastori (ured.), Teški metali i pesticidi u zemlijištu, Institut za ratarstvo i povrtarstvo, Novi Sad 187-197

Bogdanović D (2009): Potrošnja đubriva u našoj zemlji od početka hemizacije do danas, XII Kongres društva za proučavanje zemljišta Srbije, Zbornik Abstrakata, 146

Krauss M, Wilcke W, Zech W (2000): Reactivity and bioavailability of PAHs and PSBs in urban soils of Beyreuth, Proceedings First International Conference Soils of Urban, Industrial, Traffic and Mining Areas (eds. W Burghardt and C Dornauf), Essen 12-18 July, Vol, III, 657-661

Manojlović S (1986,): Sistem kontrole plodnosti zemljišta i upotrebe dubriva u Vojvodini - od naučnih istraživanja, preko razvojnih istraživanja do funkcionisanja u poljorivrednoj proizvodnji Vojvodine, Zbornik radova Pokrajinskog komiteta za nauku i informatiku, 18: 123-127

Nešić Lj, Pucarević M, Sekulić P, Belić M, Vasin J, Ćirić V (2008): Osnovna hemijska svojstva u zemljištima Srema, Zbornik radova Instituta za ratarstvo i povrtarstvo, Novi Sad 45: 255-263

Statistical Office of the Republic of Serbia (2010): Republički zavod za statistiku: Statistički godišnjak Srbije

Sekulić P, Nešić Lj, Hadžić V, Belić M, Vasin J, Ubavić M, Bogdanović D, Čuvardić M, Dozet D, Pucarević M, Miloševiš N, Jarak M, Đurić S, Ralev J, Škorić-Zeremski T (2005): Zemljišta Srbije kao resurs održivog razvoja, Plenarni referat na XI Kongresu Društva za proučavanje zemljišta Srbije i Crne Gore, Budva 13,-16, septembar 2005, Plenarni referati i abstrakti, 18-37

Sekulić P, Ninkov J, Hristov N, Vasin J, Šeremešić S, Zeremski-Škorić T (2010): Sadržaj organske materije u zemljištima AP Vojvodine i mogućnost korišćenja žetvenih ostatatka kao obnovljivog izvora energije. Ratar. Povrt. / Field Veg. Crop Res. 47: 591-598

Vasin J, Sekulić P, Kurjački I (2004): Stanje plodnosti zemljišta $\mathrm{u}$ Vojvodini, Zbornik radova Naučnog instituta za ratarstvo i povrtarstvo, Novi Sad 42: 149-155

Vasin J, Sekulić P, Kurjački I (2006): Plodnost oraničnih površina u privatnom vlasništvu u Vojvodini, Zbornik radova Naučnog instituta za ratarstvo i povrtarstvo, Novi Sad 42: 149-155

Živković B, Nejgebauer KV, Tanasijević Đ, Miljković N, Stojković L, Drezgić P (1972): Zemljišta Vojvodine, Institut $3 a$ poljoprivredna istraživanja, Novi Sad

Wu Q, Blume HP, Rexilius L, Abend S, Schleuss U (1998): Sorption of organic chemicals in Urbic Anthrosols. Adv. GeoEcol. 31: 781-789

Republic of Serbia (2009): Law on Agricultural Soils, Official Gazette of the Republic of Serbia, Issues No. 62/06, 65/08 and $41 / 09$ 


\title{
Plodnost oranica ratarskih proizvodnih rejona Vojvodine u privatnom vlasništvu
}

\author{
Stanko Milić ${ }^{1}$ Jovica Vasin ${ }^{1} \cdot$ Jordana Ninkov $^{1} \bullet$

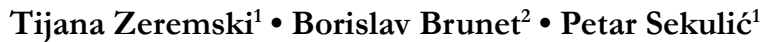

\author{
${ }^{1}$ Institut za ratarstvo i povrtarstvo, Maksima Gorkog 30, 21000 Novi Sad, Srbija \\ ${ }^{2}$ Pokrajinski sekretarijat za poljoprivredu, vodoprivredu i šumarstvo, Bul. Mihajla Pupina 16, 21000 Novi Sad, Srbija
}

Izvod: U radu su prikazani rezultati analize plodnosti zemljišta izdvojeni u odnosu na proizvodne rejone u Vojvodini. Analiza je obuhvatila 76.868 uzoraka zemljišta koji pripadaju oraničnom načinu korišćenja, što predstavlja $87 \%$ od ukupnog broja uzoraka. Neutralna reakcija zemljišta, koja je i najpovoljnija za biljnu proizvodnju, zastupljena je u 1/4 uzoraka i u zavisnosti od regiona kreće se od 12,6\% (severna Bačka) do 46,5\% (severni Srem). Ako se posmatra sadržaj slobodnog $\mathrm{CaCO}_{3}$ po rejonima, najveća srednja vrednost $(10,54 \%)$ kao i zastupljenost u klasama karbonatno $(30,6 \%)$ i jako karbonatno $(53,1 \%)$ utvrđena je za rejon severna Bačka, a najniže vrednosti ovih karakteristika za rejon severni Srem. Rezultati ispitivanja obezbeđenosti zemljišta humusom pokazuju da sva tri rejona u Srema većim delom pripadaju slabo humoznoj klasi i to od 72,1\% do $83,3 \%$ sa veoma malim udelom uzoraka humoznih zemljišta $16,2 \%$ do $27,3 \%$. Analiza sadržaja lakopristupačnog fosfora za celokupno područje Vojvodine pokazuje da se u klasu optimalne obezbeđenosti zemljišta fosforom može svrstati samo trećina uzoraka. Zabrinjavajuće je da znatan deo uzoraka spada u vrlo siromašnu (6,9\%) i siromašnu klasu (15,5\%), dok oko 7\% pripada klasama sa štetnim i toksičnim sadržajem ovog makrohraniva. Najveći broj uzoraka u pogledu sadržaja lakopristupačnog kalijuma u ispitivanim proizvodnim rejonima nalazi se u klasama optimalne i visoke obezbeđenosti, čija se suma kreće u intervalu od $77,4 \%$ do $94,1 \%$.

Ključne reči: kontrola plodnosti, zemljište, osnovna hemijska svojstva, proizvodni rejoni 